\title{
Analisis Kesehatan Keuangan Bank Syariah Mandiri Ditinjau dari Faktor Permodalan (CAR), Pembiayaan (FDR), Profitabilitas (ROA \& ROE) Serta Risiko Kredit (NPF)
}

\author{
Awan Kostrad Diharto \\ Fakultas Ekonomi dan Bisnis Islam (FEBI) IAIN Surakarta \\ *Email korespondensi: awan_kostrad@yahoo.com
}

Abstract
The aims of the research is to find out the financial soundness of Bank Syariah Mandiri (BSM) seen from the capital factor (CAR), financing (FDR), profitability (ROA \& ROE), and credit risk (NPF). This research uses quantitative descriptive methods. The data used are the 2014-2018 financial statements. The results of this study indicate that BSM in terms of capital using the CAR ratio shows an average CAR ratio of $14.75 \%$. This means that BSM in terms of capital is ranked very well. This means that BSM's ability to generate profits is ranked quite well. Bank Syariah Mandiri in terms of financing using the FDR ratio shows an average FDR ratio of $79.81 \%$. This means that BSM's ability to repay short-term loans and meet agreed financing is at a healthy rating. Bank Syariah Mandiri in terms of profitability using the ROA and ROE ratio shows an average ROA of $0.53 \%$ and ROE of $6 \%$. Bank Syariah Mandiri in terms of credit risk using the NPF ratio shows an average NPF ratio of 3.18\%. This means that there is very little credit provided by Bank Syariah Mandiri and the bank is viewed from the aspect of credit risk, including in a good rating. From the results of these research, indicate that the the soundness level of Bank Syariah Mandiri (BSM) is in a good level of soundness.

Keywords: financial soundness; capital; financing; profitability; credit risk

Saran Sitasi: Diharto, A. K. (2020). Analisis Kesehatan Keuangan Bank Syariah Mandiri Ditinjau dari Faktor Permodalan (CAR), Pembiayaan (FDR), Profitabilitas (ROA \& ROE) Serta Risiko Kredit (NPF). Jurnal Ilmiah Ekonomi Islam, 6(03), 396-402. doi: http://dx.doi.org/10.29040/jiei.v6i3.1403

DOI: http://dx.doi.org/10.29040/jiei.v6i3.1403

\section{PENDAHULUAN}

Kegiatan perekonomian yang ada di masyarakat hampir tidak dapat terlepaskan dari lembaga keuangan saat ini terutama lembaga keuangan perbankan, baik bank syariah maupun bank konvensional. Kondisi yang umum terjadi dimana surplus sektor keuangan yang ada pada masyarakat untuk menyimpan uang yang mereka miliki maupun kondisi defisit sektor untuk melakukan pengajuan permodalan atau pinjaman. Masyarakat sebelum memutuskan tempat penyimpanan uangnya, tentunya mereka akan memilih lembaga keuangan yang memiliki kesehatan keuangan yang baik dan bahkan tingkat kesehatan keuangannya sangat baik. Hal tersebut mereka lakukan dalam rangka memberikan ketenangan dan rasa aman ketika mereka menyimpan uangnya di bank tersebut. Kinerja perbankan terutama kinerja keuangan akan menjadi perhatian para nasabahnya (Farooq \& Zaheer, 2015);
(Al-Hares, dkk, 2013); (Rozzani and Rahman, 2013); (Amelia, 2015).

Ditinjau dari sudut pandang syariah bank ada dua jenis, yaitu Bank Konvensional dan Bank Syariah (bank umum syariah (BUS) \& unit usaha syariah (UUS). Perbedaan dari bank tersebut terletak pada akad serta prinsip yang akan digunakan dalam melakukan transaksi dengan nasabahnya. Bank konvensional berlandaskan bunga dari pokok pinjaman serta dalam beroperasi berprinsip meraih tingkat keuntungan sebesar-besarnya tanpa melihat manajemen serta kondisi hasil usaha dari nasabahnya. Berdasarkan syariat Islam dengan adanya pengenaan bunga menurut sebagian besar ulama merupakan riba yang sangat dilarang dan dibenci Allah dan Rasul serta merupakan perbuatan dosa besar (Gilani, 2015); (Alamgir, 2016). Disisi yang lain Bank syariah dalam beroperasi menggunakan bagi hasil sebagai salah satu prinsipnya serta menghindari adanya berbagai praktek 
riba. Bank syariah menggunakan prinsip-prinsip syariat Islam dengan senantiasa mengacu kepada ketentuan-ketentuan yang ada pada kitab Allah SWT (Qur'an) maupun Hadits Nabi SAW (Wilardjo, 2005); (Jalil \& Rahman, 2010); (Iqbal \& Molyneux, 2016); (Wulandari dan Subagio, 2015).

Bank syariah sebagai intermediasi masyarakat diharapkan mampu tampil memberikan yang terbaik jika dibandingkan dengan bank konvensional. Keberadaan bank syariah ini dengan mengunakan konsep pelarangan penerapan bunga dalam berbagai transaksi karena termasuk riba (Uusmani and Taqī 'Usmānī, 2002); (Chong \& Liu, 2009); (Farooq, 2011); (Tho'in, Irawati \& Lee, 2018); (Nasim \& Mediawati, 2019). Umat Islam dan seluruh masyarakat tentunya sangat mengharapkan bank syariah ini dapat berkembang semakin baik serta tingkat kesehatan keuangannya juga bagus. Pengukuran tingkat kesehatan bank yang dilakukan pemerintah tentunya melalui Bank Indonesia yaitu dengan menerbitkan peraturan BI nomor 13/1/PBI/2011 tentang penilaian tingkat kesehatan bank umum pada tanggal 5 Januari 2011. Kemudian lebih detail tentang tata cara penilaiannya diterangkan dalam Surat Edaran Bank Indonesia nomor 13/ 24 /DPNP tanggal 25 Oktober 2011.

Bank adalah badan usaha di bidang keuangan yang menarik dan mengeluarkan uang dalam masyarakat, terutama memberikan kredit dan jasa dalam lalu lintas pembayaran dan peredaran uang. Syariah menurut Kamus Besar Bahasa Indonesia adalah hukum agama yang menetapkan peraturan hidup manusia, hubungan manusia dengan Allah, hubungan manusia dengan manusia, dan alam sekitar berdasarkan Al-Quran dan hadis (Indonesia, K. B. B., \& Bahasa, T. P. K. P., 2015).

Laporan keuangan dalam akuntansi bank syariah adalah laporan keuangan yang memberikan sebuah gambaran fungsi bank Islam sebagai investor, hak dan kewajiban, dengan tidak memandang tujuan bank Islam dari masalah investasinya, apakah ekonomi atau sosial (Hassan dan Harahap, 2010). Tujuan pembuatan laporan keuangan adalah untuk memberikan informasi mengenai posisi keuangan, kinerja keuangan dan arus kas yang bermanfaat bagi berbagai pihak pengguna laporan dalam pembuatan keputusan ekonomi (Iatridis, 2010); (Minnis, 2011). Melalui laporan keuangan akan dapat dinilai kemampuan perusahaan untuk memenuhi kewajiban-kewajiban jangka pendeknya, struktur modal perusahaan, distribusi dan keefektifan pengggunaan aktiva, hasil usaha/pendapatan yang telah dicapai, beban-beban yang harus dibayar serta nilai-nilai buku tiap lembar saham perusahaan yang bersangkutan. Peraturan Bank sentral (BI) perihal penilaian tingkat kesehatan bank umum adalah Peraturan Bank Indonesia nomor 13/ 1/PBI/2011 yang dikeluarkan tanggal 5 Januari 2011. Kemudian lebih detail tentang tata cara penilaiannya diterangkan dalam Surat Edaran Bank Indonesia nomor 13/ 24 /DPNP tanggal 25 Oktober 2011. Penilaian Tingkat Kesehatan Bank berdasarkan peraturan tersebut mencakup penilaian terhadap faktor-faktor berikut: Profil Risiko, Good Corporate Governance, Earning, dan Capital Permodalan.

Bank Syariah Mandiri merupakan salah satu bank syariah yang berkembang dengan baik, hal ini dibuktikan dengan semakin eksisnya lembaga keuangan ini serta laporan keuangan yang dirilisnya menjadikan masyarakat semakin percaya dengan adanya lembaga keuangan ini. Oleh sebab itu ketertarikan untuk melihat kinerja keuangannya selama ini sangat diperlukan.

\section{METODOLOGI PENELITIAN}

Penelitian ini menggunakan metode deskriptif kuantitatif. Data yang digunakan adalah laporan keuangan yang dipublikasikan oleh Bank Syariah Mandiri (BSM) periode tahun 2014 sampai tahun 2018 atau selama 5 tahun. Metode analisis dalam penelitian ini adalah menggunakan rumus penghitungan faktor permodalan dalam hal ini yaitu dengan menggunakan rasio CAR, faktor pembiayaan dengan menggunakan rasio FDR, faktor profitabilitas dengan menggunakan rasio ROA \& rasio ROE, serta dari faktor risiko kredit yaitu dengan menggunakan rasio NPF.

\section{HASIL PENELITIAN}

Secara garis besar, selama lima tahun Laporan Keuangan Bank Syariah Mandiri (BSM) digambarkan pada tabel di bawah ini: 


\begin{tabular}{|c|c|c|c|c|c|}
\hline \multicolumn{6}{|c|}{$\begin{array}{c}\text { Jurnal Ilmiah Ekonomi Islam, 6(03), 2020, } 398 \\
\text { Tabel 1. Ikhtisar Keuangan BSM Tahun 2014-2018 }\end{array}$} \\
\hline \multirow{2}{*}{$\begin{array}{l}\text { Ikhtias Keuangan } \\
\quad \text { (RP miliar) }\end{array}$} & \multicolumn{5}{|c|}{$\begin{array}{ll}\text { Tahun } \\
\end{array}$} \\
\hline & 2014 & 2015 & 2016 & 2017 & 2018 \\
\hline \multicolumn{6}{|l|}{ Neraca } \\
\hline Modal & 4.937 & 5.613 & 6.392 & 7.314 & 8.039 \\
\hline Modal Inti, Pelengkap, Tambahan & 5.570 & 6.187 & 6.942 & 7.844 & 8.566 \\
\hline Total Aktiva & 66.955 & 70.369 & 78.831 & 87.915 & 98.341 \\
\hline Dana Pihak Ketiga & 59.821 & 62.113 & 69.950 & 77.903 & 87.471 \\
\hline ATMR & 37.746 & 48.146 & 49.555 & 49.350 & 52.670 \\
\hline Pembiayaan yang diberikan & 32.654 & 33.443 & 34.787 & 34.739 & 37.007 \\
\hline \multicolumn{6}{|l|}{ Pembiayaan bermasalah } \\
\hline Dalam perhatian khusus & 2.637 & 3.095 & 2.479 & 1.880 & 1.154 \\
\hline Kurang lancar & 601 & 530 & 355 & 470 & 206 \\
\hline Diragukan & 208 & 201 & 215 & 347 & 101 \\
\hline Macet & 601 & 509 & 701 & 89 & 289 \\
\hline \multicolumn{6}{|l|}{ Laba/rugi } \\
\hline Laba sebelum pajak & 110 & 374 & 434 & 487 & 815 \\
\hline Laba usaha & 99 & 369 & 442 & 470 & 839 \\
\hline Beban bagi hasil & 2.451 & 2.438 & 2.339 & 2.541 & 2.659 \\
\hline Laba bersih & 72 & 289 & 325 & 365 & 605 \\
\hline
\end{tabular}

Sumber: Laporan Tahunan 2014-2018

Berdasarkan laporan tahunan pada tabel di atas, menunjukkan bahwa secara keseluruhan posisi atau tingkat kesehatan Bank Syariah Mandiri selama periode 2014-2018 dalam keadaan yang sangat baik.

3.1 Penilaian Kesehatan Bank Syariah Mandiri (BSM) dari Faktor Permodalan dengan Menggunakan Rasio CAR

Tabel 2. Perhitungan Permodalan (CAR) dan Penilaian Peringkat BSM 2014-2018

\begin{tabular}{|c|c|c|c|c|c|}
\hline Tahun & Modal (Rp) & ATMR (Rp) & CAR & Peringkat & Predikat \\
\hline 2014 & 5.570 .000 .000 .000 & 37.746 .000 .000 .000 & $14,76 \%$ & 1 & Sangat baik \\
\hline 2015 & 6.187 .000 .000 .000 & 48.146 .000 .000 .000 & $12,85 \%$ & 1 & Sangat baik \\
\hline 2016 & 6.942 .000 .000 .000 & 49.555 .000 .000 .000 & $14,01 \%$ & 1 & Sangat baik \\
\hline 2017 & 7.844 .000 .000 .000 & 49.350 .000 .000 .000 & $15,89 \%$ & 1 & Sangat baik \\
\hline 2018 & 8.566 .000 .000 .000 & 52.670 .000 .000 .000 & $16,26 \%$ & 1 & Sangat baik \\
\hline
\end{tabular}

Sumber: data diolah

Hasil perhitungan rasio CAR menggunakan rumus yang telah ditetapkan diketahui bahwa CAR 2014 sebesar 14,76\%. Pada tahun 2015 mengalami penurunan sebesar $1,91 \%$ menjadi $12,85 \%$. Mulai tahun 2016 sampai tahun 2018 selalu terjadi kenaikan. Tahun 2016 kenaikan sebesar $1,16 \%$ menjadi $14,01 \%$. Tahun 2017 kenaikan sebesar 1,88\% menjadi 15,89\% dan tahun 2018 terdapat kenaikan sebesar 0,37\% menjadi $16,26 \%$. Pada tabel di atas dapat diketahui bahwa nilai CAR tertinggi dicapai pada tahun 2018. Artinya faktor permodalan selama periode tersebut sangat baik. 
Jurnal Ilmiah Ekonomi Islam, 6(03), 2020, 399

\subsection{Penilaian Kesehatan Bank Syariah Mandiri dari Faktor Pembiayaan dengan Menggunakan Rasio FDR}

Tabel 3. Perhitungan Pembiayaan (FDR) dan Penilaian Peringkat BSM 2014-2018

\begin{tabular}{|c|c|c|c|c|c|}
\hline Tahun & $\begin{array}{c}\text { Kredit yang diberikan } \\
(\mathrm{Rp})\end{array}$ & Dana pihak ketiga (Rp) & FDR & Peringkat & Predikat \\
\hline 2014 & 49.133 .000 .000 .000 & 59.821 .000 .000 .000 & 82,13 & 2 & Sehat \\
\hline 2015 & 51.090 .000 .000 .000 & 62.113 .000 .000 .000 & 82,25 & 2 & Sehat \\
\hline 2016 & 55.580 .000 .000 .000 & 69.950 .000 .000 .000 & 79,46 & 2 & Sehat \\
\hline 2017 & 60.584 .000 .000 .000 & 77.903 .000 .000 .000 & 77,77 & 2 & Sehat \\
\hline 2018 & 67.752 .000 .000 .000 & 87.471 .000 .000 .000 & 77,46 & 2 & Sehat \\
\hline
\end{tabular}

Sumber: data diolah

Hasil perhitungan rasio FDR menggunakan rumus yang telah ditetapkan diketahui bahwa FDR 2014 sebesar 82,13\%. Pada tahun 2015 sebesar $82,25 \%$. Perkembangan selalu lebih baik sejak tahun 2016 sebesar 79,46\%, kemudian tahun 2017 sebesar 77,77\%. FDR paling baik dicapai pada tahun 2018 sebesar $77,46 \%$. Dari data tersebut dapat diketahui bahwa dari tahun 2014 sampai tahun 2018 peringkat FDR selalu berada pada peringkat dua. Artinya kesehatan Bank Syariah Mandiri berdasarkan rasio pembiayaan (FDR) selama periode tersebut pada ketegori sehat.

\subsection{Penilaian Kesehatan Bank Syariah Mandiri (BSM) dari Faktor Profitabilitas dengan Menggunakan Rasio ROA dan ROE}

Tabel 4. Perhitungan Profitabilitas (ROA) dan Penilaian Peringkat BSM 2014-2018

\begin{tabular}{|c|c|c|c|c|c|}
\hline Tahun & Laba sebelum pajak $(\mathrm{Rp})$ & Total Asset $(\mathrm{Rp})$ & ROA & Peringkat & Predikat \\
\hline 2014 & 110.000 .000 .000 & 66.955 .000 .000 .000 & $0,16 \%$ & 4 & Kurang baik \\
\hline 2015 & 374.000 .000 .000 & 70.369 .000 .000 .000 & $0,53 \%$ & 3 & Cukup baik \\
\hline 2016 & 434.000 .000 .000 & 78.831 .000 .000 .000 & $0,55 \%$ & 3 & Cukup baik \\
\hline 2017 & 487.000 .000 .000 & 87.915 .000 .000 .000 & $0,55 \%$ & 3 & Cukup baik \\
\hline 2018 & 815.000 .000 .000 & 98.341 .000 .000 .000 & $0,83 \%$ & 3 & Cukup baik \\
\hline
\end{tabular}

Sumber: data diolah

Hasil perhitungan rasio ROA menggunakan rumus yang telah ditetapkan diketahui bahwa ROA 2014 sebesar 0,16\%. Pada tahun 2015 sampai dengan tahun 2018 selalu terjadi kenaikan. Tahun 2015 ROA menjadi 0,53\%, tahun 2016 dan 2017 ROA menjadi $0,55 \%$ dan tahun 2018 ROA pada posisi tertinggi sebesar $0,83 \%$. Dari data tersebut dapat diketahui bahwa tahun 2014 rasio ROA masih kurang baik. Namum demikian selanjutnya terjadi peningkatan, di mana sejak tahun 2015 sampai dengan tahun 2018 peringkat ROA selalu pada posisi 3 , artinya faktor kamampuan bank dalam menghasilkan laba dari sisi asset yang dimiliki cukup baik.

Tabel 5. Perhitungan Profitabilitas (ROE) dan Penilaian Peringkat BSM 2014-2018

\begin{tabular}{|c|c|c|c|c|c|}
\hline Tahun & Laba setelah pajak (Rp) & Rata-rata modal disetor $(\mathrm{Rp})$ & ROE & Peringkat & Predikat \\
\hline 2014 & 72.000 .000 .000 & 4.937 .000 .000 .000 & $1,46 \%$ & 4 & Kurang baik \\
\hline 2015 & 289.000 .000 .000 & 6.187 .000 .000 .000 & $5,15 \%$ & 3 & Cukup baik \\
\hline 2016 & 325.000 .000 .000 & 6.942 .000 .000 .000 & $5,08 \%$ & 3 & Cukup baik \\
\hline 2017 & 365.000 .000 .000 & 7.844 .000 .000 .000 & $4,99 \%$ & 4 & Kurang baik \\
\hline 2018 & 605.000 .000 .000 & 8.566 .000 .000 .000 & $7,53 \%$ & 3 & Cukup baik \\
\hline
\end{tabular}

Sumber: data diolah

Hasil perhitungan rasio ROE menggunakan rumus yang telah ditetapkan diketahui bahwa ROE 2014 sebesar $1,46 \%$. Terjadi peningkatan signifikan pada tahun 2015 menjadi sebesar 5,15\%. Selanjutnya tahun 2016 sebesar 5,08\%, tahun 2017 terjadi penurunan menjadi 4,19\% dan tahun 2018 ROE kembali meningkat dan berada pada posisi tertinggi sebesar 7,53\%. Dari data tersebut dapat diketahui 


\section{Jurnal Ilmiah Ekonomi Islam, 6(03), 2020, 400}

bahwa tahun 2014 dan 2017 rasio ROE masih kurang baik. Namum demikian selanjutnya terjadi peningkatan signifikan pada tahun 2015 dan 2018.

Peringkat ROE secara umum ada pada posisi 3, artinya faktor kamampuan bank dalam menghasilkan laba bersih dari sisi setoran modal cukup baik.

\subsection{Penilaian Kesehatan Bank Syariah Mandiri dari Faktor Risiko Kredit dengan Menggunakan Rasio NPF}

Tabel 6. Perhitungan NPF dan Penilaian Peringkat BSM 2014-2018

\begin{tabular}{|c|c|c|c|c|c|}
\hline Tahun & Pembiayaan $(\mathrm{KL}, \mathrm{D}, \mathrm{M})(\mathrm{Rp})$ & Total Pembiayaan $(\mathrm{Rp})$ & NPF & Peringkat & Predikat \\
\hline 2014 & 1.410 .000 .000 .000 & 32.654 .000 .000 .000 & 4,32 & 2 & Baik \\
\hline 2015 & 1.240 .000 .000 .000 & 33.443 .000 .000 .000 & 3,71 & 2 & Baik \\
\hline 2016 & 1.271 .000 .000 .000 & 34.787 .000 .000 .000 & 3,65 & 2 & Baik \\
\hline 2017 & 906.000 .000 .000 & 34.739 .000 .000 .000 & 2,61 & 2 & Baik \\
\hline 2018 & 596.000 .000 .000 & 37.007 .000 .000 .000 & 1,61 & 1 & Sangat Baik \\
\hline
\end{tabular}

Sumber: data diolah

Hasil perhitungan rasio NPF menggunakan rumus yang telah ditetapkan diketahui bahwa NPF 2014 sebesar $4,32 \%$. \%. Tahun-tahun berikutnya selalu terjadi perkembangan lebih baik, dimulai tahun 2015 menjadi sebesar $3,71 \%$, kemudian tahun 2016 sebesar $3,65 \%$, tahun 2017 sebesar 2,61\%. NPF paling baik dicapai pada tahun 2018 sebesar 1,61\%. Dari data tersebut dapat diketahui bahwa dari tahun 2014 sampai tahun 2017 peringkat NPF selalu berada pada peringkat dua, yaitu predikat baik. Kemudian tahun 2018 terjadi peningkatan ke predikat sangat baik.

Adapun rata-rata dari penilaian seluruh faktor dapat dilihat pada tabel berikut ini:

Tabel 7. Rata-rata Peringkat BSM 2014-2018

\begin{tabular}{|c|c|c|c|c|c|}
\hline Tahun & Faktor & Rasio & Peringkat & Predikat & Rata-rata peringkat \\
\hline \multirow{5}{*}{2014} & CAR & $14,76 \%$ & 1 & Sangat baik & \multirow{5}{*}{2,6} \\
\hline & ROA & $0,16 \%$ & 4 & Kurang baik & \\
\hline & ROE & $1,46 \%$ & 4 & Kurang baik & \\
\hline & FDR & $82,13 \%$ & 2 & Sehat & \\
\hline & NPF & $4,32 \%$ & 2 & Baik & \\
\hline \multirow[t]{5}{*}{2015} & CAR & $12,85 \%$ & 1 & Sangat baik & \multirow{5}{*}{2,2} \\
\hline & ROA & $0,53 \%$ & 3 & Cukup baik & \\
\hline & ROE & $5,15 \%$ & 3 & Cukup baik & \\
\hline & FDR & $82,25 \%$ & 2 & Sehat & \\
\hline & NPF & $3,71 \%$ & 2 & Baik & \\
\hline \multirow[t]{5}{*}{2016} & CAR & $14,01 \%$ & 1 & Sangat baik & \multirow{5}{*}{2,2} \\
\hline & ROA & $0,55 \%$ & 3 & Cukup baik & \\
\hline & ROE & $5,08 \%$ & 3 & Cukup baik & \\
\hline & FDR & $79,46 \%$ & 2 & Sehat & \\
\hline & NPF & $3,65 \%$ & 2 & Baik & \\
\hline \multirow[t]{5}{*}{2017} & CAR & $15,89 \%$ & 1 & Sangat baik & \multirow{5}{*}{2,4} \\
\hline & ROA & $0,55 \%$ & 3 & Cukup baik & \\
\hline & ROE & $4,99 \%$ & 3 & Kurang baik & \\
\hline & FDR & $77,77 \%$ & 2 & Sehat & \\
\hline & NPF & $2,61 \%$ & 2 & Baik & \\
\hline \multirow[t]{5}{*}{2018} & CAR & $16,26 \%$ & 1 & Sangat baik & \multirow{5}{*}{2} \\
\hline & ROA & $0,83 \%$ & 3 & Cukup baik & \\
\hline & ROE & $7,53 \%$ & 3 & Cukup baik & \\
\hline & FDR & $77,46 \%$ & 2 & Sehat & \\
\hline & NPF & $1,61 \%$ & 1 & Sangat Baik & \\
\hline \multicolumn{5}{|c|}{ Rata-rata Peringkat } & 2,28 \\
\hline \multicolumn{5}{|c|}{ Predikat } & Sehat \\
\hline
\end{tabular}

Sumber: data diolah 


\section{Jurnal Ilmiah Ekonomi Islam, 6(03), 2020, 401}

Berdasarkan tabel 7 pada rata-rata peringkat dapat diketahui bahwa hasil penilaian kesehatan selama lima tahun terakhir Bank Syariah Mandiri berada pada predikat sehat. Dari tahun 2014 hingga tahun 2018 aspek permodalan menunjukkan rasio CAR selalu berada pada peringkat satu. Artinya faktor permodalan Bank Syariah Mandiri selama periode tersebut sangat baik. Kemudian dari aspek profitabilitas, rasio ROA tahun 2014 menunjukkan predikat kurang baik. Namun demikian tahun 2015 sampai 2018 rasio ROA meningkat menjadi cukup baik. Demikian pula rasio ROE, predikat kurang baik terjadi pada tahun 2014 dan 2017. Akan tetapi terjadi perbaikan di tahun 2015, 2016 dan 2018 menjadi cukup baik, sehingga secara rata-rata predikat selama lima tahun adalah cukup baik. Dari rasio tersebut dapat diketahui bahwa kemampuan menghasilkan laba Bank Syariah Mandiri baik dari sisi aset yang dimiliki maupun dari sisi modal yang disetor cukup baik. Tingkat likuiditas yang dinilai dari rasio FDR tahun 2014-2018 berada pada peringkat 2 atau predikat sehat. Dari sini dapat disimpulkan bahwa tingkat kemampuan Bank Syariah Mandiri untuk melunasi kewajiban jangka pendeknya tepat pada waktunya dan kemampuan memenuhi semua permohonan kredit yang telah disetujui sangat baik. Kualitas pembiayaan Bank Syariah Mandiri dilihat dari rasio NPF berpredikat baik pada tahun 2014-2017, sedangakan tahun 2018 meningkat sampai pada predikat sangat baik.

\section{KESIMPULAN}

Berdasarkan hasil analisis penelitian pada bab sebelumnya, maka dapat disimpulkan bahwa tingkat kesehatan Bank Syariah Mandiri (BSM) berdasarkan rata-rata peringkat dengan menggunakan rasio permodalan, rasio profitabilitas, rasio pembiayaan, dan rasio risiko kredit selama lima tahun (2014-2018) termasuk bank syariah yang sehat.

\section{UCAPAN TERIMA KASIH}

Terima kasih disampaikan kepada Bapak Dr. Rahmawan Arifin, SE., M.Si selaku Dekan Fakultas Ekonomi dan Bisnis Islam IAIN Surakarta beserta jajarannya yang telah memberikan dukungan serta berbagai fasilitas atas terlaksananya penelitian ini.

\section{DAFTAR PUSTAKA}

Alamgir, M. (2016). An analysis of islamic banking activities in Bangladesh: Issues and challenges. Thoughts on Economics, 25(03), 2958.

Al-Hares, O. M., AbuGhazaleh, N. M., \& El-Galfy, A. M. (2013). Financial performance and compliance with Basel III capital standards: Conventional vs. Islamic banks. Journal of Applied Business Research (JABR), 29(4), 10311048.

Amelia, E. (2015). Financial Ratio and Its Influence to Profitability in Islamic Banks. Al-Iqtishad: Jurnal Ilmu Ekonomi Syariah, 7(2), 229-240.

Chong, B. S., \& Liu, M. H. (2009). Islamic banking: interest-free or interest-based?. Pacific-Basin finance journal, 17(1), 125-144.

Farooq, M. O. (2011). Qarụ Hasan, Wadī 'ah/Amānah and Bank Deposits: Applications and Misapplications of Some Concepts in Islamic Banking. Arab Law Quarterly, 25(2), 115-146.

Farooq, M., \& Zaheer, S. (2015). Are Islamic banks more resilient during financial panics?. Pacific Economic Review, 20(1), 101-124.

Gilani, H. (2015). Exploring the ethical aspects of Islamic banking. International Journal of Islamic and Middle Eastern Finance and Management.

Hassan, A., \& Harahap, S. S. (2010). Exploring corporate social responsibility disclosure: the case of Islamic banks. International Journal of Islamic and Middle Eastern Finance and Management.

Iatridis, G. (2010). International Financial Reporting Standards and the quality of financial statement information. International review of financial analysis, 19(3), 193-204.

Indonesia, K. B. B., \& Bahasa, T. P. K. P. (2015). Jakarta: Balai Pustaka, 2005. Cetakan Pertama Edisi Ketiga.

Iqbal, M., \& Molyneux, P. (2016). Thirty years of Islamic banking: History, performance and prospects. Springer.

Jalil, A., \& Rahman, M. K. (2010). Financial transactions in Islamic Banking are viable alternatives to the conventional banking transactions. International Journal of Business and Social Science, 1(3). 
Minnis, M. (2011). The value of financial statement verification in debt financing: Evidence from private US firms. Journal of accounting research, 49(2), 457-506.

Nasim, A., \& Mediawati, E. (2019). Critical Study the Application of the Principle of Profit Sharing in Syirkah Mudharabah and Musyarakah in Islamic Banking. KnE Social Sciences, 1351-1359.

Rozzani, N., \& Rahman, R. A. (2013). Camels and performance evaluation of banks in Malaysia: conventional versus Islamic. Journal of Islamic Finance and Business Research, 2(1), 36-45.

Surat Edaran Bank Indonesia nomor 13/ 24 /DPNP tanggal 25 Oktober 2011. Penilaian Tingkat Kesehatan Bank mencakup penilaian terhadap faktor-faktor berikut: Profil Risiko, Good Corporate Governance, Earning, dan Capital Permodalan. Diakses pada tanggal 4 Maret 2020.
Tho'in, M., Irawati, T., \& Lee, M. (2018). Risk and Financial Health Level of Shariabanking. Journal Research and Analysis: Economy, 1(1), 19-26.

Uusmani, M. T., \& Taqī 'Usmānī, M. (2002). An introduction to Islamic finance (Vol. 20). Brill.

Wilardjo, S. B. (2005). pengertian, peranan dan perkembangan bank syari'ah Di Indonesia. Value Added | Majalah Ekonomi Dan Bisnis, 2(1).

Wulandari, D., \& Subagio, A. (2015). Consumer decision making in conventional banks and islamic bank based on quality of service perception. Procedia-Social and Behavioral Sciences, 211, 471-475. 